\title{
Perforation of the Right Ventricle as a Complication of Pericardiocentesis: A Case report
}

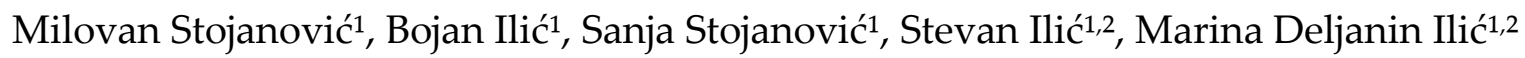 \\ IInstitute for Treatmen and Rehabilitation "Nǐ̌ka Banja", Niš, Serbia \\ 2University of Niš, Faculty of Medicine, Niš, Serbia
}

\begin{abstract}
SUMMARY
Pericardial effusion represents the accumulation of larger amounts of fluid in the pericardial cavity. If not timely diagnosed and adequately treated, it can lead to cardiac tamponade. The treatment of pericardial effusion includes primarily the use of drugs like aspirin, NSAIDs, corticosteroids, and/or colchicine followed by invasive procedures such as pericardiocentesis or pericardiectomy. Pericardiocentesis complications are extremely rare but very serious especially in the case of the rupture of the right ventricle or the coronary arteries. Patient S.V, born in 1938, from Svrljig, was examined because of suffocating and swollen shin. The medical reports showed that the patient previously had had a permanent pacemaker implanted and that he had undergone a triple coronary artery bridging. Medical reports also showed that two months before the examination he was hospitalized due to pericardial effusion at the reference institution. The ultrasonographic examination registered large circular effusion with the motion of the right ventricle and the patient underwent urgent pericardiocentesis. During pericardiocentesis, the rupture of the right ventricle occurred and the patient was sent to the cardiac surgery clinic where he had catheter extraction performed. The control ultrasound examination of the heart showed no pericardial effusion, and no signs of damage to the right ventricle.
\end{abstract}

Key words: pericardial effusion, pericardiocentesis, rupture of the right ventricle 


\section{INTRODUCTION}

Pericardial effusion represents the accumulation of larger amounts of fluid in the pericardial cavity. Normally, the pericardium contains $15-50 \mathrm{ml}$ of liquid that represents plasma ultrafiltrate which is quite sufficient for pericardium to perform its basic task and that is to prevent friction and mechanical damage to the heart during systole and diastole.

In certain cardiac and extracardial diseases as well, larger amounts of fluid in the pericardium may acummulate, which, if not timely diagnosed and adequately treated, can lead to cardiac tamponade. Etiology occurrence of pericardial effusion is diverse and includes infective agents on the one side (usually viruses and bacteria) and non-infectious causes on the other (renal failure, hypothyroidism, cancer, posttraumatic effusion, post-radiation, autoimmune, etc.), while the idiopathic pericardial effusion is an entity by itself. In developed countries, idiopathic pericardial effusion dominates with over $50 \%$, while pericardial effusion caused by Mycobaceterium tuberculosis is the most common in developing countries, up to $60 \%(1,2)$. Effusion often occurs as a result of exudation of fluid but can also occur as a transudate, mostly in heart weakness or in conditions of impaired colloid osmotic pressure such as liver cirrhosis or nephrotic syndrome. Effusion may be serous, hemorrhagic, purulent, which usually depends on the etiopathogenesis of its generation.

\section{CASE REPORT}

The patient S.V., born in 1938, from Svrljig, came for examination because of suffocation and swelling of the lower leg. After examining the medical records we get the information that the patient survived a heart attack of anteroseptal localization in 2003. Coronary angiography verified the multivessel coronary disease and the patient was suggested to undergo surgical revascularization.

Coronary artery bypass grafting triple bypass was done in 2004 at the Institute for Cardiovascular Diseases Dedinje (LIMA RIA, OM1, RCA). Ultrasound examination was done: EF 45\%, septal hypokinesia, with no free fluid in the pericardium. Therapy on discharge: beta blocker, ACE inhibitor, acetyl-salicylic acid, statine, antibiotics (azithromycin).

The patient did not have symptoms until 2007, when he started to feel frequent dizziness, fainting with several episodes of loss of consciousness due to which he was hospitalized in the reference institution where he was, due to newly registered bradyarrhythmia absolute, implanted a permanent artificial heart operation guide (pacemaker, PM). Therapy on discharge: aminophylline, calcium channel antagonist, acetyl-salicylic acid, ranitidine, redergin, warfarin.

In September, 2014, the patient was hospitalized again at the competent institution, due to suffocation, shin and stomach swelling. The ECG rhythm PM with SF 75/min, elevated serum troponin, creatinine, urea and urine acid. Due to suspicion of acute coronary syndrome, the patient undergwent MSCT of coronary vessels which showed that all the grafts were clear. The ultrasound examination of the heart showed: increased diameters of right heart cavities with reduced contractile force, EF $48 \%$, and a circular pericardial effusion in the level of atrial grooves to $35 \mathrm{~mm}$ in front of the tip of the heart $10 \mathrm{~mm}, 15 \mathrm{~mm}$ in front of the right ventricle, left atrium $9 \mathrm{~mm}$ front and behind the lateral wall $15 \mathrm{~mm}$ with dilated inferior vena cava partial inspiratory collapse and bilateral pleural effusions. Thyroid hormones were within the referential values. The antiinflammatory therapy was included and contained corticosteroids and ibuprofen. The ultrasound examination of the heart made shortly before the discharge of the patient showed pericardial effusion with the same dimensions, with the motion of the right ventricle and with visible adhesions especially around the tip and the lateral wall. The patient was discharged in stable condition with a recommendation for further treatment: beta blockers, nitrates, acetyl-salicylic acid, a proton pump inhibitor, ibuprofen $3 \times 400 \mathrm{mg}$ the next 10 days, furosemide 40 mg daily, and was advised to visit the cardiologist for control examination in a month.

In November of the same year, the patient was admitted to the outpatient clinic at Institute "Niška Banja" due to suffocation and lower legs swellings. ECG showed PM rhythm, SF 75/min (Figure 1). During the examination, the left lung basal inspirium cracks were found, and auscultatory on the heart, the activity was rhythmical, tones were dull, TA 120/70 $\mathrm{mmHg}$, SF 70/min. The ultrasound examination of the heart showed circular pericardial effusion in front of the right ventricle $20 / 11 \mathrm{~mm}$, posterior $46 / 42 \mathrm{~mm}$, lateral $36 / 33 \mathrm{~mm}$, with a deflection of the free wall of the right ventricle, many pleuropericardiac adhesions and bilateral pleural effusion (Figure 2). The patient 
was referred to reference center for pericardiocentesis and for an attempt to comprehend the etiology of the existing effusion.

The patient was admitted to hospital the same day at the competent institution where pericardiocentesis was started after the preoperative procedure. In the course of the procedure lesions of the right heart occurred, which was confirmed by ultrasound and heart X-ray, and the patient accompanied by a doctor was sent to the Department of Cardiology of the Cardiovascular Institute Dedinje (Figure 3).

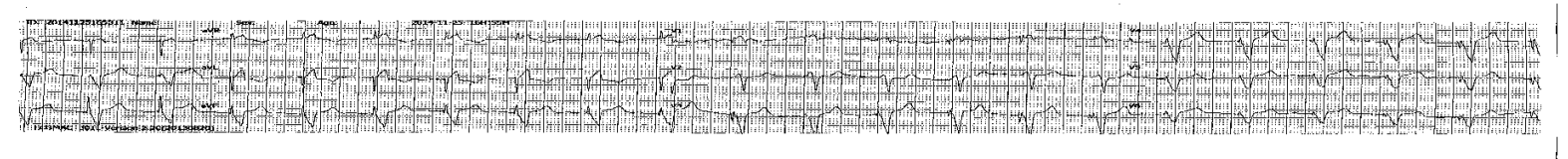

Figure 1. ECG done at the emergency unit at the Institute "Niška Banja"

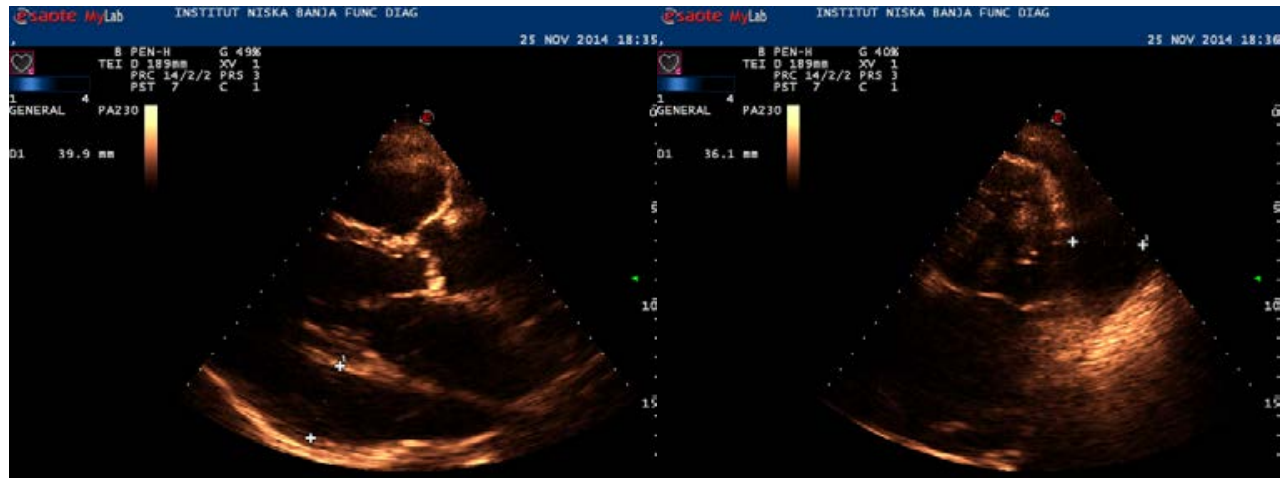

Figure 2. Ultrasound examination of the heart, made at the emergency unit at the Institute "Niska Banja

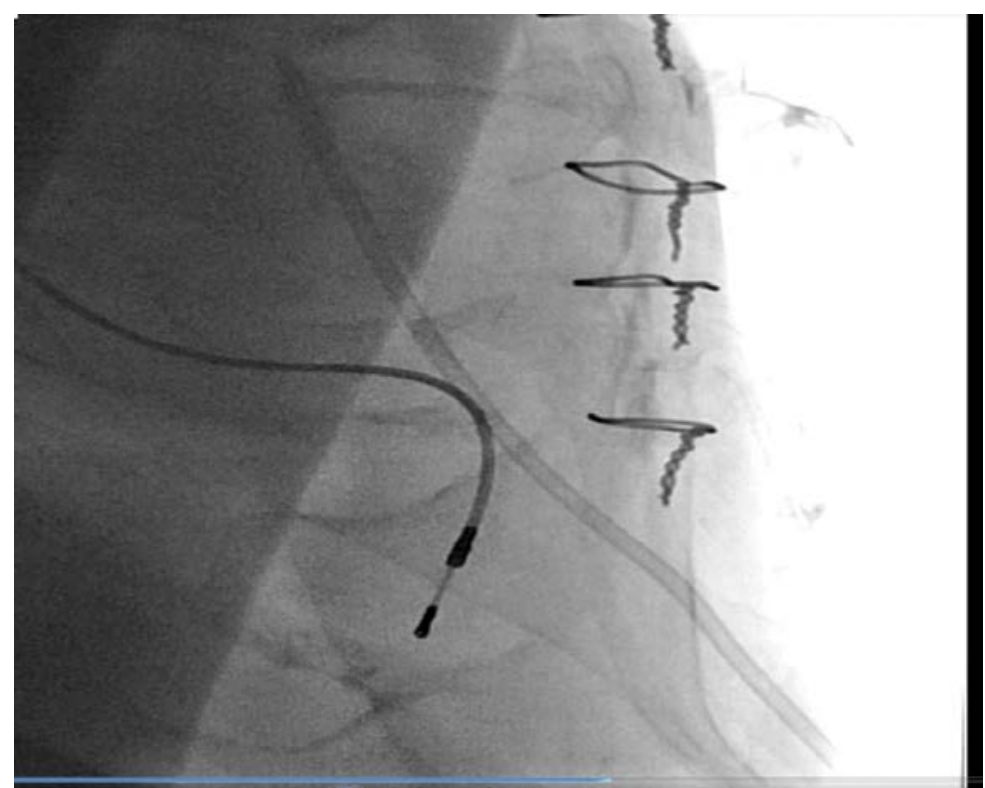

Figure 3. Pericardiocentesis and "jammed" catheter in the right ventricle

The ultrasound examination of the heart done after the hospitalization of the patient at the Institute for Cardiovascular Diseases Dedinje confirmed the presence of the catheter in the right ventricle. On the 
same day, retoractomy with extirpation of a foreign body was done. The postoperative course was complicated with the signs of heart failure with spontaneous pneumothorax, which spontaneously drained. The ultrasound examination of the heart made just before the release of the patient showed: EF $50 \%$, no pericardial effusion, and with vena cava inferior of normal size. The patient was transferred to the reference institution for a prolonged hospitalization with the following treatment: acetylsalicylic acid, ACE inhibitor, furosemide, spironolactone, statin, warfarin.

During the hospitalization at the reference institution, the control of the heart did not show the presence of free fluid in the pericardium. The patient was discharged in a stable condition, with the following therapy: acetylsalicylic acid, ACE inhibitor, spionolactone, furosemide, a proton pump inhibitor and statin.

The control ultrasound examination of the heart at the Institute "Niška Banja" showed: EF 45\%, no pericardial effusion, and preserved diameters of cardiac chambers. Patient has not had cardiovascular problems since intervention.

\section{DISCUSSION}

The prognosis of pericardial effusion depends not only on the absolute amount of fluid that accumulates in the pericardium but also on the speed of its accumulation and the state of the located pericardium. Sometimes, even quite a small effusion of 200-300 ml can lead to tamponade if liquid accumulates quickly, because there is a sudden increase in intrapericardial pressure (3). Therefore, it is very important to know whether the effusion is small, moderate or large but also whether it is acute, subacute or chronic in order to make any prognosis. Large spills of more than $20 \mathrm{~mm}$ in one third of the cases lead to tampnade of the heart if not adequately and timely treated (4). Another problem is naturally quite a long latent period. That is why there is a great discrepancy between the registered pericardial effusions when a patient is alive and when effusion is registered at autopsy (5).
Clinical manifestation of pericardial effusion is quite non-specific and includes symptoms such as suffocation, orthopnea, discomfort in the chest as well as the symptoms that occur due to compression of the surrounding mediastinal structures (dysphagia, hoarsness, hiccups, nausea, etc.). Also, the physical findings, ECG and laboratory can stay and mostly remain unchanged. Therefore, for the diagnosis of pericardial effusion the most reliable imaging methods are used (ECHO, X-ray, MRI, CT) (6-10). There especially stands an ultrasound examination of the heart as the gold standard because it can demonstrate not only the localization but also the size of pericardial effusion and, most importantly, whether there is a risk for the occurrence of cardiac tamponade.

The treatment of pericardial effusion should be causal because in about $60 \%$ of detected effusions the cause is known (11). With idiopathic effusion, it is usually based on the use of medicaments such as acetyl salicylic acid, non-steroidal anti-inflammatory drugs, corticosteroids and/or colchicine (12). However, in certain situations when drug treatment remains unsuccessful and the patient is threatened by tamponade, it is necessary to do emergency pericardiocentesis or pericardiectomy.

Pericardiocentesis is an invasive drainage procedure of pericardial effusion. A significantly smaller percentage of complications occur if the pericardial effusion is bigger and if the procedure itself is guided by ultrasound (1). The most common complications are infections, vagal bradycardia, pneumothorax, arrhythmias, as well as perforation of the myocardium or coronary arteries. The incidence of complications is significantly reduced by $1 \%$ using the ultrasound and ranges from 1 to $1.6 \%(13)$.

\section{CONCLUSIONS}

An example of our patient confirms the need of imaging-guided pericardiocentesis as the use of ultrasound or $X$ ray in the course of the procedure significantly reduces the possibility of complications. 


\section{References}

1. Imazio M, Yehuda A. Management of pericardial effusion. European heart journal 2012; Vol 34(16):1186-97.

http://dx.doi.org/10.1093/eurheartj/ehs372.

2. Syed FF, Ntsekhe M, Mayosi BM. Tailoring diagnosis and management of pericardial disease to the epidemiological setting. Mayo ClinProc 2010;85:866.

http://dx.doi.org/10.4065/mcp.2010.0377

3. Deljanin-Ilić M. Pericarditis. In:Ilić S. (ed), Internamedicina 2009; Galaksija,Niš: 806-13.

4. Sagrista-Sauleda J, Angel J, Permanyer-Miralda G, Soler-Soler J. Long-termo following up of idiopathic chronic pericardial effusion. N Eng J Med 1999;341:2054-9.

http://dx.doi.org/10.1056/NEJM199912303412704

5. Imazio M, Mayosi BM, Brucato A et al. Triage and management of pericardial effusion. J Cardiovasc Med 2010;11:928-35.

http://dx.doi.org/10.2459/JCM.0b013e32833e5788

6. Yared K, Baggashi AL, Picard MH. Multimodality imaging of pericardial disease. JACC Cardiovasc Imaginig 2010;3:650-60. http://dx.doi.org/10.1016/j.jcmg.2010.04.009

7. Verharter D, Gabriel RS, Johnston D. The role of multimodality imaging in the mengament of pericardial disease. Circ Cardiovasc Imaging 2010;3:333-43.

http://dx.doi.org/10.1161/CIRCIMAGING.109.92 1791
8. Rajiah P, Kanne JP. Computed tomography of the pericardium and pericardial disease. J Cardiovasc Comput Tomogr 2010; 4:3-18. http://dx.doi.org/10.1016/j.jcct.2010.01.004

9. Imazzio M, Brucato A, Decrosa FG et al. Aethiological diagnosis an acute and recurentpericarditis: when and now. J Cardiovasc Med 2009;10:217-30. http://dx.doi.org/10.2459/JCM.0b013e328322f9b1

10. Bogaert J, Francone M. Cardiovascular magnetic resonance in pericardial disease. J CardiovascMagn Reason 2009;11:11-4. http://dx.doi.org/10.1186/1532-429x-11-14

11. Sagrista-Sauleda J, Merce J, Permanyer-Miralda G, Soler-Soler J. Clinical clues to the causes of large pericardial effusion. Am J Med 2000;109:95101.

http://dx.doi.org/10.1016/S0002-9343(00)00459-9

12. Imazio $\mathrm{M}$, Brucato $\mathrm{A}$, Trinchero $\mathrm{R}$ et al. Colchicin for pericarditis: hype or hope? Eur Heart J 2009;30:532-9.

http://dx.doi.org/10.1093/eurheartj/ehn608

13. Maish B, Seferović PM, Ristić AD et al. Task force on the diagnosis anf Management of Pericardial disease on the European Society of Cardiology. Guidelines on the diagnosis and management of pericardial disease executive summary: the Task force on the diagnosis and management of pericardial diease of the European Society of Cardiology. Eur Heart J 2004;25:587-610.

http://dx.doi.org/10.1016/j.ehj.2004.02.002 


\title{
Perforacija desne komore kao komplikacija perikardiocenteze: prikaz slučaja
}

\author{
Milovan Stojanović ${ }^{1}$, Bojan Ilić ${ }^{1}$, Sanja Stojanović ${ }^{1}$, Stevan Ilićc ${ }^{1,2}$, Marina Deljanin Ilićc ${ }^{1,2}$ \\ 'Institut za lečenje i rehabilitaciju "Niška Banja", Niš, Srbija \\ ${ }^{2}$ Univerzitet u Nišu, Medicinski fakultet, Niš, Srbija
}

\section{SAŽETAK}

Perikardni izliv predstavlja nakupljanje veće količine tečnosti u perikardnoj šupljini. Ukoliko se pravovremeno ne dijagnostikuje $i$ adekvatno ne tretira, može dovesti do tamponade srca. Terapija perikardnog izliva obuhvata, pre svega, upotrebu lekova i to aspirina, NSAIL, kortikosteroida i/ili kolhicina, a potom $i$ invazivne procedure poput perikardiocenteze ili perikardiektomije. Komplikacije perikardiocenteze su izuzetno retke ali vrlo ozbiljne pogotovu kada se govori o rupturi desne komore ili koronarnih arterija. Bolesnik S.V, rođen 1938.godine iz Svrljiga, dolazi na pregled zbog gušenja i otoka potkolenica. Iz medicinske dokumentacije se dobijaju podaci da je bolesnik od ranije implantiran stalni pejsmejker, kao i da je imao operaciju trostrukog aortokoronarnog premošćavanja. Takođe, dobija se podatak da je dva meseca pre pregleda bio hospitalizovan na Klinici za kardiologiju KC Niš zbog perikardnog izliva. Na ultrazvučnom pregledu registrovan je veliki cirkularni izliv sa ugibanjem desne komore pa je bolesnik upućen na hitnu perikardiocentezu. $U$ toku perikardiocenteze dolazi do rupture desne komore zbog čega je bolesnik upućen na Kardiohiruršku kliniku, gde mu je izvršena ekstrakcija katetera. Kontrolni ultrazvučni pregled srca pokazuje da nema perikardnog izliva i znakova oštećenja desne komore.

Ključne reči: perikardijalni izliv, perikardiocenteza, rupture desne komore 